\title{
National Academy of Engineering 2019 Simon Ramo Founders Award Remarks
}

\author{
Cato T. Laurencin, M.D., Ph.D.: Winner of the 2019 Simon Ramo Founders Award \\ of the National Academy of Engineering
}

Cato T. Laurencin

Farmington, USA

(Published online 31 July 2020)

Thank you, National Academy of Engineering, for awarding me this singular honor.

Regenerative Engineering is the Convergence of technologies that a generation ago might not be thought to be connected. ${ }^{1-11}$ I am humbled that the work I've accomplished in creating a fundamentally new field has been acknowledged by the National Academy of Engineering. The work continues to provide new knowledge, new science and ultimately provides new solutions for those I consider the ultimate heroes, our patients.

I am the first individual to win both the oldest/ highest award of the National Academy of Engineering (the Simon Ramo Founder's Award) and the oldest/highest award of the National Academy of Medicine (the Walsh McDermott Medal). I am receiving both this month. It underscores the achievements of the Laurencin Labs over the past 30 years. I am indeed blessed.

I am the first engineer-physician to receive the Founder's Award. I believe that engineering, which is the bridge between Science and Society, has as its future revolutionizing medical care in the coming decades. It is my belief that the improvement in outcomes of patients in this century will largely hinge on the Convergence of engineering principles with the life sciences.

I am also the first Black person to receive the Founders Award of the National Academy of Engineering. I want to make sure that the importance of the struggle Black people have had collectively for me to be here today is not lost. In the words of the Negro National Anthem,

Address correspondence to Cato T. Laurencin, Farmington, USA. Electronic mail: laurencin@uchc.edu
"Stoney the road we trod,

Bitter the chast'ning rod,

Felt in the days when hope, unborn, had died;

Yet with a steady beat,

Have not our weary feet

Come to the place for which our fathers sighed?

We have come over a way that with tears has been watered.

We have come treading our path through the blood of the slaughtered,

Out from the gloomy past,

Till now we stand at last

Where the white gleam of our bright star is cast."

And in the words of Maya Angelou,

"I am a Black Ocean, leaping and wide.

Welling and swelling I bear in the tide."

"Bringing the gifts that my ancestors gave.

I am the dream and the hope of the slave.

I rise

I rise

I rise."

I am appreciative. And, as my friend Richard Farr believes, being appreciative is a cornerstone of one's being.

I would like to first provide my appreciation to Professor Robert Langer, my mentor, who taught me how to be a scientist and is responsible for so much good in my career and in my life. Bob, thank you.

I want to thank those who have helped provide guidance and inspiration to me scientifically including Professor Nicholas Peppas who is here today, Professor Shu Chien and Professor Y.C. Fung (who with Nich are Founder's Award winners). I want to thank my science family, Professor Lakshmi Nair, Professor Yusuf Khan, and Professor Kevin Lo-all former students-who each have moved multiple times to stay with me. I am appreciative. 
I want to acknowledge and thank the Academy presidents I have worked with over the years including Dan Mote, Victor Dzau, Harvey Fineberg, and dear, dear Charles Vest, who first befriended me when I was a faculty member at MIT.

This life would not have been possible but for my parents, Helen I. Moorehead Laurencin, M.D. and Mr. Cyril Laurencin. My mom was a family doctor who delivered compassionate care, performed surgical procedures, and had a lab on the first floor of our house, and my dad was a master carpenter and inventor. My life is a tribute to them. For both my parents, mens et manus was the theme, i.e. mind and hand were equally important to cultivate. Thus, I am an engineer and an orthopaedic surgeon, both fields bringing mens et manus to bear. There is a Chewa African Proverb that states that a child brought up where there is dancing cannot fail to dance. I can attest to the veracity of this. My siblings and I grew up in an intellectual environment that could be likened to a discotheque meeting a ballet studio. To my late parents, I am appreciative.

Finally, my greatest discovery, scientific or otherwise, has been my wife and life partner, Cynthia Laurencin. We have spent over $70 \%$ of our adult lives together, and to paraphrase the artist $\mathrm{Ne}-\mathrm{Yo}$, we are a true force when we're together. We are blessed with three wonderful children. They are truly the joy of our lives. To my wife and children, I love you. Thank you. I am appreciative.

I want to close by again thanking the National Academy of Engineering for bestowing upon me the Simon Ramo Founders Award. Since I am provided a short time for my remarks I will not be able to have an extended discussion on my philosophy of life. So I leave you all just one piece of philosophical advice from what I've gleaned from my life to date.

Love More, Worry Less, and above all, Be Appreciative.

Thank you.

\section{ACKNOWLEDGEMENTS}

Dr. Laurencin received the NIH Director's Pioneer Award for his work in Regenerative Engineering: NIH PIONEER (DP1AR068147). He is a recipient of the Presidential Award for Excellence in Science, Math and Engineering Mentoring from President Barack Obama in ceremonies at the White House (2009) and the National Medal of Technology and Innovation, presented by President Barack Obama in ceremonies at the White House (2016). He received the Biomedical Engineering Society (BMES) Diversity Award in 2011.

\section{REFERENCES}

${ }^{1}$ Laurencin, C. T., and A. McClinton. Regenerative cellbased therapies: cutting edge, bleeding edge, and off the edge. Regen. Eng. Transl. Med. 6, 78-89, 2020. https://doi. org/10.1007/s40883-020-00147-1.

${ }^{2}$ Otsuka T., A. Phan, C. T. Laurencin, J. D. Esko, S. V. Bryant, and D. M. Gardiner. Identification of heparansulfate rich cells in the loose connective tissues of the Axolotl (Ambystoma mexicanum) with the potential to mediate growth factor signaling during regeneration. Regen. Eng. Transl. Med. 6:7-17, 2020. https://doi.org/10.1007/s4 0883-019-00140-3.

${ }^{3}$ Tang, X., N. Saveh-Shemshaki, H. M. Kan, Y. Khan, and C. T. Laurencin. Biomimetic electroconductive nanofibrous matrices for skeletal muscle regenerative engineering. Regen. Eng. Transl. Med. 2019. https://doi.org/10.1007/s4 0883-019-00136-z.

${ }^{4}$ Barajaa, M. A., L. S. Nair, and C. T. Laurencin. Bioinspired scaffold designs for regenerating musculoskeletal tissue interfaces. Regen. Eng. Transl. Med. 2019. https://d oi.org/10.1007/s40883-019-00132-3.

${ }^{5}$ Xiaoyan, T., L. Daneshmandi, G. Awale, L. S. Nair, C. T. Laurencin. Skeletal muscle regenerative engineering. Regen. Eng. Transl. Med. 5:233-251, 2019. https://doi.org/10. 1007/s40883-019-00102-9.

${ }^{6}$ Ogueri, K., T. Taheri, and J. Escobar, C. T. Laurencin. Polymeric biomaterials for scaffold-based bone regenerative engineering. Regen. Eng. Transl. Res. 5(2):128-154, 2019. https://doi.org/10.1007/s40883-018-0072-0.

${ }^{7}$ Nelson, C., Y. Khan, C. T. Laurencin. (2018). Nanofiber/ microsphere hybrid matrices in vivo for bone regenerative engineering: a preliminary report. Regen. Eng. Transl. Med. 4(3):133-141. https://doi.org/10.1007/s40883-018-00 55-1.

${ }^{8}$ Ogueri, K. S., J. L. Escobar Ivirico, L. S. Nair, H. R. Allcock, and C. T. Laurencin. Biodegradable polyphosphazene-based blends For regenerative engineering. Regen. Eng. Transl. Med. 3(1):15-31, 2017. https://doi.org/10.100 7/s40883-016-0022-7.

${ }^{9}$ Narayanan, G., M. Bhattacharjee, L. S. Nair, and C. T. Laurencin. Musculoskeletal tissue regeneration: the role of the stem cells. Regen. Eng. Transl. Med. 3(3):133-165, 2017. https://doi.org/10.1007/s40883-017-0036-9.

${ }^{10}$ Kasir, R., V. N. Vernekar, and C. T. Laurencin. Regenerative engineering of cartilage using adipose derived stem cells. Regen. Eng. Transl. Med. 1, 42-49, 2015. https://doi. org/10.1007/s40883-015-0005-0.

${ }^{11}$ Laurencin, C. T., and L. S. Nair. Regenerative Engineering. Approaches to limb regeneration and other grand challenges. Regen. Eng. Transl. Med. 1:1-3, 2015. https://d oi.org/10.1007/s40883-015-0006-z.

Publisher's Note Springer Nature remains neutral with regard to jurisdictional claims in published maps and institutional affiliations. 